\title{
OPPORTUNITIES FOR THE DEVELOPMENT OF A GREEN ORGANISATION IN THE CONTEXT OF NATIONAL AND INTERNATIONAL STRATEGIC DOCUMENTS AND INICIATIVES
}

\author{
Ilona SKAČKAUSKIENE்(D, Juliana SMIRNOVA®* \\ Department of Management, Faculty of Business Management, Vilnius Gediminas Technical University, \\ Saulètekio al. 11, 10223, Vilnius, Lithuania
}

Received 26 February 2021; accepted 1 April 2021

\begin{abstract}
The article emphasizes the aspects of organisational development in the context of green organisation, describing the importance of changes in an external environment for the development of the organisation.

Purpose - the purpose of the article is to analyse the relevance of green organisation development at the national and international levels by examining it through the prism of strategic documents and initiatives. In order to determine the development directions of the green organisation on the basis of strategic documents and initiatives.

Research methodology - the methods of critical analysis of scientific literature, strategic documents, initiatives and synthesis as well as abstrahation have been applied.

Findings - main findings of the research proved that development of green organisation is relevant in the context of key international and national strategic documents. Also the definition of the development of green organisations is proposed by authors. The analysis of strategic documents and initiatives at the national and international levels has shown that their impact on the development of a green organisation can be both direct and indirect.

Research limitations - the limitation of this reseach is that mainly key international and national strategic documents were analyzed. Analysis of other strategic documents can be stated as a direction for future research.

Practical implications - the results of the research could be used as a basis for the promotion of the development of green organisations at the national and international level both directly and indirectly.

Originality/Value - the originality of this research can be defined by complex approach to analysis related to the impact of actual legal regulation to the development of green organisations.
\end{abstract}

Keywords: organizational development, green organization, green organisational identity, sustainable development, government regulations.

JEL Classification: M10, M14, M16.

Conference topic: Contemporary Organizations Development Management.

\section{Introduction}

In today's world, sustainable development and green growth are given increasingly great attention. It can be said that the creation of green organisations is one of the outcomes of these global aspirations. Green organisations integrate green initiatives and practices into their activities in different areas in meeting their environmental objectives, social well-being and economic growth. This dynamic world sees constant changes that encourage the development of organisations, so green organisations are developing accordingly. In a systematic approach, the development of an organisation is inseparable from changes in the external environment. The external environment consists of several different components that affect the organisation's activities. This paper analyses the influence of the legal component (factor) on the development of a green organisation.

The purpose of this article is to identify opportunities for the development of a green organisation based on the analysis of national and international strategic documents and initiatives. For this purpose, the paper first examines the term of "development", emphasising its versatility and complexity, and also refines the concept of "green organi-

*E-mail: juliana.smirnova@vilniustech.lt

(C) 2021 Authors. Published by Vilnius Gediminas Technical University. This is an open-access article distributed under the terms of the Creative Commons Attribution (http://creativecommons.org/licenses/by/4.0/) License, which permits unrestricted use, distribution, and reproduction in any medium, provided the original author and source are credited. 
sation development". The analysis of national and international documents not only dealt with their content, but also looked into the perspectives they point out, i.e. refined the opportunities for the development of a green organisation by exploiting the legal environment. Methods of research: critical analysis of scientific literature, strategic documents, initiatives, and abstrahation, and synthesis. The analysis (and synthesis) of strategic documents has shown that the development of green organisations is promoted at the national and international level both directly and indirectly. Legal instruments that have a direct impact on the development of a green organisation include those that regulate the activities that reveal green organisational identity, i.e. relating to the pursuit of environmental, economic development and/or social welfare objectives. Indirect impact covers initiatives to raise public awareness of the drive for achieving a balance between the increase of productivity and the goals of sustainable development and green growth.

\section{Aspects of the development of an organisation in the context of a green organisation}

In examining the development of an organisation, it can be noticed that the concept of "development" is understood differently. Sen, a Nobel Memorial Prize laureate in Economic Sciences (1999) defined development as "the process of expanding human rights". The Cambridge Dictionary (2021) defines development as "the process in which someone or something grows or changes and becomes more advanced". Different interpretations of the concept are sometimes supplemented by differences in translation into different languages. In English, one word "development" is used. For example, when translating "development" into Lithuanian, different terms that have different interpretations are found in different sources: development, expansion. Dictionary of Contemporary Lithuanian translates the English term "development" as expansion, growth. Since the term is described in different terms, it is given different contents. An interesting difference between the meanings of the concepts of development and expansion is provided by Ambrusevič (2011). Agreeing with Hoff et al. (2000) and Stern (2002), the author describes expansion as a process focused on creating new opportunities and increasing economic outcomes. Referring to Šimelevič and Bagdzevičienè (2002), Ambrusevič (2011) points out that development involves structural changes in the economic system. Agreeing with Burinskienè (2010), Ambrusevič (2011) argues that although the concept of expansion is often confused with growth, the former is much broader and associated with qualitative changes resulting from the use of more advanced technologies. Oželienė (2019), agreeing with Balčiūnaitienė (2016), defines development as progress, modernisation, continuous growth process, i.e. qualitative changes in the course of social and economic progress. According to the author, the term development is more associated with quantitative changes, and growth more closely reflects gradual changes. Šimelevič and Bagdzevičienè (2002) present the modern concept of development, based on the proposal of Filipov and Avdejeva (2000) to examine development through the prism of three interrelated criteria: change, growth, and improvement. The modern concept of development proposed by Šimelevič and Bagdzevičienè (2002) is based on the idea that change leads to growth, and growth leads to improvement. Šimelevič and Bagdzevičienè (2002) propose examining development as a multifaceted process that leads to radical changes in social, institutional, and administrative structures, people's behaviour as well as to accelerating economic growth and the elimination of disparities. In summary, it can be said that in Lithuanian language different interpretations of the concept of development, expansion, growth have similar meanings and are used to describe the process of changes leading to significant change and improvement. Still it is obvious that different translation of the term "development" may lead to the different interpretations of the concept. In analysing the aspects of organisational development, it is expedient to refer to the organisational development theory. According to Zakarevičius (2002), the methods proposed by the organisational development theory have been devised in accordance with the general methodology of systematic analysis in order to apply the possibilities of systematic analysis, and a special methodology - organisational design - has been developed within the framework of this concept. According to the author, the main components of the process of organisational design are identified as follows:

- diagnostics, analysis and assessment of the external environment;

- diagnostics, analysis and assessment of the internal organisational situation;

- clarification and adjustment of the organisation's goals;

- selection of the type and form of the organisational structure, taking into account all possible options;

- division and regimentation of functions, determination of the number of employees;

- design of employee work organisation.

It is clear that the assessment of the external environment is an integral aspect of an organisation's development. According to the scientific literature, the external environment of an organisation consists of many factors. One of the examples of the categorisation of the external environment components is presented in the PESTEL external environment analysis methodology, where external factors are divided into political, economic, social, technical, ecological and legal ones. With reference to the organisational development theory and systemic approach, it can be said that the development of an organisation is a process based on continuous improvement of internal processes in response to ongoing changes in the internal and external environment. In examining development in the context of a green organisation, it can be said that the very need for green organisations arose in response to changes in the global society in order to achieve the goals of mitigation of the impact of climate change and sustainable development. 
Agreeing with Tseng et al. (2013), Soewarno et al. (2019) points that environmental issues have become a serious problem of the world today, firms around the world are currently under strict environmental pressures. The author agrees with Chan (2005), Foley and Olabi (2017), Campiglio et al. (2018) that the impact of drastic climate change has created an awareness in governments, firms and civil societies around the world regarding the importance of preserving the environment. According to Chen (2011), under the huge change, it is not only necessary to adopt a preventive approach to environmental pollution to protect the environment, but also important to improve business model. Agreeing with Fernandez et al. (2003), Chen (2011) points that if environmental issues result in positive associations in the organisational identity, they would create emotional associations in the managing interpretations and would stimulate the search for opportunities in their behaviour. Chen (2011) refers to Albert and Whetten (1985) and defines "green organisational identity" as an interpretive scheme about environmental management and protection that members collectively construct in order to provide meaning to their behaviours. With reference to the study conducted by Chen (2011), it can be argued that green organisational identity covers many areas: green design, green marketing, green products, green production as well as other areas of activity of the organisation. It is important to mention that green organisational identity is not limited to environmental aspects alone. The aspiration of society to sustainable development should be considered as the precondition for the emergence of a green organisation. According to the authors, sustainable development is a process which not only meets the needs of present-day people, but also meets the needs of generations to come. According to Ning et al. (2018) the essential features of sustainable development are resource conservation, pollution reduction, and output increases. Based on the definition given by the Ministry of Environment of the Republic of Lithuania, sustainable development is a path for the development of a modern and responsible state and its society, which is based on three equal policy areas: environmental protection, economic development, and social well-being. Agreeing with McCann-Erickson (2007), Kushwaha and Sharma (2016) defines sustainability is a collective term for everything to do with responsibility for the world in which we live it is an economical, social and environmental issue. The values of a green organisation are consistent with the principles of sustainable development, so it can be said that the concept of a green organisation includes the drive for economic development, environmental protection and social well-being in its activities. In summary, it can be said that the development of green organisations takes place in response to changes in the internal and external environments and is characterised by continuous improvement of internal processes, focusing it on the green identity of the organisation in various areas of its activities. Since the development of organisations is inseparable from the impact of external factors, it is expedient to perform the diagnostics of the external environment of a green organisation when looking for opportunities for its development. This article is focused on one type of the factors in the external environment of a green organisation - legal factors. The analysis of this environment has been performed in two directions: first, the documents at the national level were analysed, and then the international documents and initiatives regulating the activities of the organisations were analysed in order to distinguish their possible impact on the development of a green organisation.

\section{Relevance of the development of a green organisation at the national and international levels}

There is not, and probably cannot be, uniform guidelines for state that would define a universal direction for green growth. International organisations, however, develop recommendations providing guidance to countries on how to work towards green growth. Based on them, countries form strategies that correspond to the general world trends but are adapted to the specifics of a particular country.

Defining the research methodology, analysis of strategic documents was performed by three steps by further sequence. Firstly, an extensive primary analysis of strategic documents related to the topic was conducted in order to refine the most important documents for further analysis. Secondly, content analysis of key strategic documents related to the topic of the development of green organisation was performed. After the analysis of the content of the related documents, the impact of legal regulation on the development of green organisations was identified.

\subsection{Impact of strategic documents at the national level on the development of a green organisation: The case of Lithuania}

The State Progress Strategy "Lithuania 2030" approved in 2012 should be considered an example of Lithuanian strategies at a national level. It is based on the ideas from communities, non-governmental organisations and active citizens on how to make Lithuania's future successful, to create an economically and socially strong state, open to the world and nurturing its identity. The vision and priorities of the State Progress Strategy "Lithuania 2030" is expressed through the indicators of progress in its implementation, which directly define the main targets to be achieved by 2030 . The special feature of the mechanism for the implementation of the Strategy is that the general public, which not only was actively involved in all stages of the development of the Strategy, but also makes proposals for the implementation of the Strategy at thematic discussions and in the Open Progress Forum, is considered to be the author of the Strategy. The State Progress Strategy "Lithuania 2030" is one of the most important documents that government 
representatives take into account when making strategic decisions. The goals of the priority directions of the State Progress Strategy "Lithuania 2030" are also targeted to the priorities of green growth. In 2012, the National Progress Programme 2014-2020 was approved for the implementation of the State Progress Strategy "Lithuania 2030". This Programme, which combines the main provisions of the State Progress Strategy "Lithuania 2030" and the European Union's Strategy "Europe 2020", describes the tasks and directions of the implementation of the long-term priorities of the state and envisages the proportions of EU financial support. The implementation of the UN's 2030 Agenda for Sustainable Development at the national level is also important for the green growth of the state. At the national level, strategic documents and initiatives are developed and approved in different sectors, which are related to the implementation of sustainable development goals and green growth of the state; therefore, it can be said that they are related to development opportunities for a green organisation (Table 1).

Table 1. The relation of the impact of strategic documents and initiatives at the national level with development opportunities for a green organisation (composed by the authors)

\begin{tabular}{|c|c|}
\hline Document title & Impact on the development of a green organisation \\
\hline $\begin{array}{l}\text { National Progress } \\
\text { Programme } \\
2014-2020 \text { of the } \\
\text { Republic of Lithuania }\end{array}$ & $\begin{array}{l}\text { Priorities: to promote the preservation of health, natural and cultural environment; to improve the well- } \\
\text { being and social inclusion of the population; to increase high-quality employment of the population; to } \\
\text { create a sustainable and efficient economic infrastructure; to promote the sustainable use of resources; } \\
\text { to ensure the stability of ecosystems. As the priorities of the Programme are related to the values of } \\
\text { a green organisation; the public awareness is promoted, preconditions are formed for the creation of } \\
\text { green organisations and the development of the existing ones. }\end{array}$ \\
\hline $\begin{array}{l}\text { State Progress } \\
\text { Strategy "Lithuania } \\
2030 \text { " of the Republic } \\
\text { of Lithuania }\end{array}$ & $\begin{array}{l}\text { The priority of the Strategy is to promote changes in } 3 \text { areas - smart society, smart economy, and } \\
\text { smart governance - with the state promoting innovative organisational solutions. The state promotes } \\
\text { the creation of a smart society, which aims at greater personal and economic security and activity, } \\
\text { more balanced distribution of income, and a clean environment, ensures social and political inclusion, } \\
\text { creates wide opportunities for learning and improving individual abilities, and seeks good human } \\
\text { health. The priority of the Strategy is directly related to the promotion of the values of a green } \\
\text { organisation. Information provided by the state raises public awareness, which encourages the search } \\
\text { for innovative solutions in organisations. When the state and society support the development of } \\
\text { responsible business, this creates favourable conditions for the development of a green organisation. }\end{array}$ \\
\hline $\begin{array}{l}\text { National Energy and } \\
\text { Climate Action Plan } \\
\text { for the period } \\
2021-2030 \text { of the } \\
\text { Republic of Lithuania }\end{array}$ & $\begin{array}{l}\text { The priority directions of the Plan include the mitigation of the impact on climate change and ambient } \\
\text { air pollution, reliability, competitiveness and the participation of the country's business in achieving } \\
\text { energy progress, for which clear goals have been set, e.g. by } 2025 \text {, Lithuania together with Latvia } \\
\text { and Estonia will synchronise, via Poland, with a reliable and unified continental European electricity } \\
\text { system. It is expected to reach a level of } 45 \% \text { renewable energy sources in final energy consumption } \\
\text { by } 2030 \text {. At least } 30 \% \text { of consumers will themselves produce electricity for their own needs. The } \\
\text { implementation of these and other non-mentioned targets in cooperation with state authorities will } \\
\text { promote the application of advanced and green technologies in organisations, which can be considered } \\
\text { as an opportunity for the development of a green organisation. }\end{array}$ \\
\hline
\end{tabular}

At the national level of the Lithuania, important are not only the latest but also previously adopted legal documents that ensure the achievement of sustainable development goals, for example, those concerning environmental protection, such as the Law of the Republic of Lithuania on Environmental Protection (1992), the Law of the Republic of Lithuania on Pollution Tax (1999), and others. It can also be stated that the documents that are being developed in response to the challenges of the COVID-19 pandemic will have an impact on the development of a green organisation. One such example is the launch of an assessment of the prospects for the development of bioeconomy in Europe and Lithuania by Kargyte and Matijošyte (2020) in order to promote biotechnology science and its broader application in Lithuania's economy in addressing global challenges for the environment and quality of life.

The analysis of the examined Lithuanian strategic documents allows assuming that the strategic documents at the national level have both direct and indirect impact on the development of a green organisation. The documents governing specific activities of organisations, thus ensuring compliance with environmental requirements and promoting the reduction of pollution, can be attributed to those that have direct impact. Documents that have indirect, but no less important, impact include strategic documents and initiatives that raise public information and awareness of the ecology and sustainable development of organisations and society, thus contributing to the values of a green organisation. The conscious involvement of members of the public is promoted through conducting public education on various issues of environmental protection, climate change mitigation and social responsibility. In the case of Lithuania, an example could be large-scale provision of information on waste sorting issues. Not only the desire of members of the public to be active in waste sorting, but also formation of initiative groups promoting reasonable consumption and "zero waste" traditions in social networks can be considered as the result of these educational activities. Another example of a success story is the Lithuanian deposit system for disposable beverage packaging, experience of which has been higly evaluated at the international level. Soewarno et al. (2019), agreeing with Chen 
et al. (2006), argue that people today have high environmental concerns, so consumers have become very sensitive to organic products. According to the authors, companies are expected to implement green innovations so that they could adapt to the expectations of stakeholders. According to the authors, green innovations mean innovations related to ecological products and processes, including energy saving, pollution management, waste recycling, product design, and environmental management. It can be said that the indirect impact on the development of a green organisation through raising public awareness is manifested through the growing need to adapt to public expectations on the issues of environmental protection and social responsibility, drive for the active implementation of green innovations and application of green practices in day-to-day activities. Also, with the growing popularity of the trends of reasonable consumption in society and the growing demand for organic products, new business models are emerging, which are also encouraging the popularity of green organisations.

\subsection{Impact of strategic documents and initiatives at the international level on the development of a green organisation}

In an international context, the Organisation for Economic Co-operation and Development (OECD) is one of the most important organisations functioning at the European level. According to the OECD's Activity Report for 2019, the greatest attention was paid to sustainable development at a global level owing to the United Nations' 2030 Agenda for Sustainable Development and the Paris Agreement on Climate Change, as the problems of lagging growth, labour market inequalities and globalisation are important for the global community. Productivity growth, green growth and inclusive growth are three key aspects of the OECD efforts to help countries sustain economic growth and improve well-being in the context of sustainable development. The OECD's Report states that in order to assess the overall sustainability of the current growth model (Figure 1), the linkages among these aspects are being continuously re-examined.

Green growth is key aspect in building the well-being of society in the context of sustainable development. In 2011, the OECD developed the Green Growth Strategy based on a "green lens" for looking at growth, development and human well-being. It recognises the full value of natural capital as a factor production along with other commodities and services. The OECD argues that current patterns of economic growth continue to erode natural capital. If left unchecked, this would mean increased water scarcity, worsening resource bottlenecks, greater pollution, climate change, and unrecoverable biodiversity loss. While there is no "one-size-fits-all" prescription for implementing green growth, the OECD's analytical work over the past years resulted in the ability to provide concrete targeted advice to member and partner countries in mainstreaming green growth into national and multilateral policies. The OECD works closely with the United Nations on the issues of the implementation of the 2030 Agenda for Sustainable Development, providing research findings and recommendations to member countries on how to implement green growth strategies. Developed in 2015, the 2030 Agenda for Sustainable Development presents a common well-being plan for a sustainable world aimed at creating a world in which all people can live productively, energetically and peacefully on a healthy planet and setting targets to be achieved by 2030. The 2030 Agenda for Sustainable Development consists of 17 sustainable development goals, 169 targets and 232 indicators to measure progress. The above OECD and UN international-level, global-scale documents are guidelines of a recommendatory nature. In 2016, the Paris Agreement on Climate Change was adopted within the United Nations Framework Convention on Climate Change and became the first universally binding agreement on the impact of climate change (United Nations Climate Change (2020), European Council, (2020)). Based on this Agreement, in 2019 the most important task and priority of the European Commission was formulated: to make Europe the world's first climate-neutral continent by 2050, and the European Green Deal was launched to achieve this goal. The Horizon Europe European Union missions, which will be carried out in 2021-2027 in implementing the EU's Horizon Europe research and innovation programme (Agency for Science, Innovation and Technology in Lithuania , 2020), should also be viewed as an important initiative for green growth. Based on the information from the European Commission, each mission will operate as a set of actions - research projects, policy measures or legislative initiatives are planned to achieve a measurable goal that could not be achieved by individual actions. The missions will contribute to achieving the objectives of the Green Deal for Europe, the European Action Plan to Combat Cancer, and sustainable development. There are 5 areas to be addressed by the missions: fight against cancer; adaptation to climate change, including societal change, vibrant oceans, marine, coastal and terrestrial waters; climate-neutral and smart cities; soil condition and food. At the end of the missions, their results will be assessed against a pre-defined set of criteria, which have been developed from November 2020. Strategic documents and initiatives that are developed at the inter-

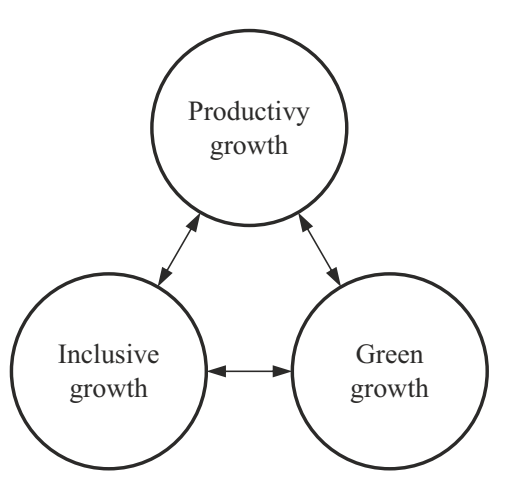

Figure 1. Structure of well-being growth model (based on OECD work on green growth, 2019) 
national level have both direct and indirect impact on green organisations and provide opportunities for their expansion (Table 2). Strategic documents that provide indicative guidelines and recommendations to countries, plans and agendas that list clear measures and evaluation criteria to achieve the objectives can be attributed to direct impact. Indirect impact includes missions, research, green initiatives to raise information and awareness of environmental, economic development and social well-being issues among members of the public.

Table 2. The impact of strategic documents and initiatives at the international level on development opportunities for a green organisation (composed by the authors)

\begin{tabular}{|c|c|}
\hline Document title & Impact on the development of a green organisation \\
\hline $\begin{array}{l}\text { Green Growth } \\
\text { Strategy (OECD) }\end{array}$ & $\begin{array}{l}\text { A key priority of the Green Growth Strategy, which is consistent with the objectives of a green } \\
\text { organisation, is the drive to accelerate investment and innovation that will support sustainable growth } \\
\text { and open up new economic opportunities. Green innovation is an integral part of the development of } \\
\text { a green organisation, which helps to improve the use of resources and reduce environmental pollution. } \\
\text { External promotion will accelerate the implementation of green innovations, which allows for their } \\
\text { broader use in organisations. }\end{array}$ \\
\hline $\begin{array}{l}\text { Paris Agreement on } \\
\text { Climate Change (UN) }\end{array}$ & $\begin{array}{l}\text { The common goal of European states to reduce pollution will have an impact on every organisation. } \\
\text { In pursuance of the objective set by the Paris Agreement on Climate Change, measures will be taken } \\
\text { at the national level to oblige organisations to take action to reduce their environmental impact. } \\
\text { One of the goals of a green organisation is to reduce the negative impact on the environment, so the } \\
\text { implementation of the Paris Agreement on Climate Change will contribute to the development of the } \\
\text { green organisation. }\end{array}$ \\
\hline $\begin{array}{l}\text { Horizon Euro } \\
\text { European Uni } \\
\text { missions }\end{array}$ & $\begin{array}{l}\text { The implementation of the priorities of these missions, in particular adaptation to climate change, } \\
\text { including societal change and the development of climate-neutral and smart cities, will support } \\
\text { research and raise the level of public involvement in addressing these problems. }\end{array}$ \\
\hline $\begin{array}{l}\text { UN } 2030 \text { Agenda } \\
\text { for Sustainable } \\
\text { Development }\end{array}$ & $\begin{array}{l}\text { Agenda } 2030 \text { consists of } 17 \text { goals, the overwhelming majority of which are consistent with the goals } \\
\text { of a green organisation. The following can be distinguished as the most important for the development } \\
\text { of a green organisation: accessible and clean energy, actions for climate conservation, responsible } \\
\text { consumption and production, reduction of inequalities, ensuring gender equality, sustainable cities and } \\
\text { communities, continuous economic growth, and cooperation towards achieving common goals. }\end{array}$ \\
\hline $\begin{array}{l}\text { Green Deal (European } \\
\text { Commission) }\end{array}$ & $\begin{array}{l}\text { The basis of the Green Deal is fundamentally consistent with the objectives of a green organisation } \\
\text { because it is aimed at investments in green technologies, sustainable solutions and new businesses, } \\
\text { which lays a good foundation for the development of a green organisation. }\end{array}$ \\
\hline
\end{tabular}

The examples of the presented documents and initiatives related to sustainable development and green growth are not limited merely to tackling ecological or environmental problems, but also deal with aspects of social well-being and sustainable economic development. It can be said that the strategic documents and initiatives at the international level influence the development of a green organisation by involving various activities that are related to the values of the green organisation - paying particular attention to tackling the problems of climate pollution by promoting investment in green technologies and sustainable solutions and raising public awareness. While analyzing strategic documents it is important to note that continuity of the documents is different. With regard to strategic documents specifics, it can be argued that strategy itself cannot be seen as a short-term document. Strategic documents that are analyzed in this article can be divided into long-term documents and very long-term documents by emphasizing their duration up to and over 10 years. Examples of long-term documents can be National Progress Programme 2014-2020 of the Republic of Lithuania, State Progress Strategy "Lithuania 2030" of the Republic of Lithuania, National Energy and Climate Action Plan for the period 2021-2030 of the Republic of Lithuania, Horizon Europe European Union Missions, Paris Agreement on Climate Change. European Green Deal and UN 2030 Agenda for Sustainable Development can be attributed to very long-term documents, because aims of these documents are planned to achieve after more than 10 years since they were announced. It is also obvious that different continuity of the documents means that different impact will be achieved because bigger complexity and scope of the objectives pursued for the very long-term strategic documents.

\section{Identifying opportunities for the development of a green organisation in the context of strategic documents and initiatives at the national and international levels}

The analysis of strategic documents and initiatives has shown that the development of green organisations is promoted at the national and international level both directly and indirectly. Legal instruments that have a direct impact on the development of a green organisation include those that regulate the activities that reveal green organisational identity, i.e. relating to the pursuit of environmental, economic development and/or social welfare objectives. Obvious exam- 
ples of such documents are environmental taxes, tax incentives for the employment of socially vulnerable people, laws on regional economic development. Recommendations and guidelines developed at the global and European Union level, on the basis of which states formulate their strategies at the national level, are also attributable to direct impact. One of the examples is the internationally announced UN's 2030 Agenda for Sustainable Development, which is being implemented at the national level. Another example is the Paris Agreement on Climate Change, on the basis of which measures will be taken at the national level to oblige organisations to take action to reduce their environmental impact. Also, the Green Deal should be considered as a strategic document of direct impact. Its main goal is to make Europe the world's first climate-neutral continent by 2050 .

Indirect impact covers initiatives to raise public awareness of the drive for achieving a balance between the increase of productivity and the goals of sustainable development and green growth. It can also be said that the promotion of advanced digital technologies and green innovations can have a significant impact at the national level. Based on the performed analysis, the following main opportunities for the development of a green organisation in the context of strategic documents and initiatives can be identified:

- regulation of climate reduction solutions can promote the development of green organisations through support to environmental initiatives;

- support to investment in advanced technologies, sustainable solutions and green innovation at the national level can promote the development of green organisations through the adoption of green technologies;

- public information and raising awareness of issues of sustainable development and green growth involve both organisations and members of the public to pursue goals that are consistent with the values of a green organisation. In this way, the creation and development of green organisations is supported by society, thus stimulating the promotion of green solutions at the national level;

- with the growing popularity of the trends of reasonable consumption in society and the growing demand for organic products, new business models are emerging, which are encouraging the popularity of green organisations;

- raising public awareness is manifested through the growing need for organisations to carry out their activities in a responsible manner and to adapt to public expectations on the issues of environmental protection and social responsibility, the drive for the active implementation of green innovations and application of green practices in day-to-day activities. This results in a synergy between growing public awareness of the issue of environmental protection and the need for the creation and development of green organisations.

To sum up, it can be stated that both direct and direct impact of the strategic documents positively affect development of green organisations and create basis for the creation of new green organisations.

\section{Conclusions}

To summarise the performed analysis of the scientific literature, we propose to define the development of green organisations as the continuous improvement of the organisation's internal processes in response to changes in the internal and external environment, focused on the green identity of the organisation being put in practice in all areas of the organisation. The development of organisations is inseparable from the impact of external factors, one of which - the legal factor - is particularly important to the development of a green organisation. This factor was examined to refine its potential impact on the development of a green organisation.

The analysis of strategic documents and initiatives at the national and international levels has shown that their impact on the development of a green organisation can be both direct and indirect. Strategic documents with a direct impact may include legal instruments that have a direct impact on the development of a green organisation include those that regulate the activities that reveal green organisational identity, relating to the pursuit of environmental, economic development and/or social welfare objectives. Direct impact covers recommendations and guidelines drawn up at the global and European Union scale, on the basis of which states formulate their strategies at the national level. It can also be said that the promotion of advanced digital technologies and green innovations can have a significant impact on development at the national level.

Indirect impact on the development of a green organisation is exerted by missions, research, green initiatives to raise information and awareness of environmental, economic development and social well-being issues among members of the public.

Assessing the development potential of a green organisation, it can be said that initiatives of national significance and international level involve government representatives, currently operating organisations, and various members of the public to work towards achieving the goals that are consistent with the values of a green organisation. It can be said that the greater the involvement of the society, the more important are green organisations, their creation and development, which in turn is more effective if supported by the state through support to the introduction of advanced technologies and support in the form of information and advice. The analysis provided in this article has shown the relevance of development of green organisations in the context of key international and national strategic documents. 
It can be stated that both direct and direct impact of the strategic documents positively affect development of green organisations and create basis for the creation of new green organisations. Limitation of this reseach is that mainly key international and national strategic documents were analyzed. Analysis of other strategic documents can be stated as a direction for future research.

\section{Disclosure statement}

Authors declare no competing financial, professional, or personal interests from other parties.

\section{References}

Agency for Science, Innovation and Technology in Lithuania. (2020). Horizontas 2020. https://mita.lrv.lt/lt/veiklos-sritys/programos-priemones/horizontas-2020

Albert, S., \& Whetten, D. (1985). Organizational identity. In L. L. Cummings \& B. M. Staw (Eds), Research in Organizational Behavior, 7 (pp. 263-295). JAI Press.

Ambrusevič, N. (2011). Internacionalizavimo procesai plètojant aukštujų technologijų sektorių: ekonominiai sprendimai [Doctoral dissertation, Vilnius Gediminas Technical University, Lithuania]. https://doi.org/10.20334/1963-M

Balčiūnaitienè, A. 2016. Darnaus vystymosi kompetencijos ugdymas aukštojo mokslo institucijose [Daktaro disertacija, Vytauto Didžiojo universitetas] (p. 132).

Burinskienè, A. (2010). Elektroninès komercijos technologiju taikymas plètojant tarptautine prekyba [Daktaro disertacija]. Socialiniai mokslai, ekonomika (04S) (p. 192). Technika.

Cambridge Dictionary. (2020). https://dictionary.cambridge.org/

Campiglio, E., Dafermos, Y., Monnin, P., Collins, J. R., Schotten, G., \& Tanaka, M. (2018). Climate change challenges for central banks and financial regulators. Nature Climate Change, 8(6), 462-468. https://doi.org/10.1038/s41558-018-0175-0

Chan, R. Y. (2005). Does the natural-resource-based view of the firm apply in an emerging economy? A survey of foreign invested enterprises in China. Journal of Management Studies, 42(3), 625-672. https://doi.org/10.1111/j.1467-6486.2005.00511.x

Chen, Y. S., Lai, S. B., \& Wen, C. T. (2006). The influence of green innovation performance on corporate advantage in Taiwan. Journal of Business Ethics, 67(4), 331-339. https://doi.org/10.1007/s10551-006-9025-5

Chen, Y. (2011). Green organizational identity: sources and consequence. Management Decision, 49(3), 384-404. https://doi. org/10.1108/00251741111120761

Dictionary of Contemporary Lithuanian. (2020). http://kiis.lki.lt/

European Council. (2020). Climate change: what the EU is doing. https://www.consilium.europa.eu/lt/policies/climate-change/ paris-agreement/

European Union. (2016). Paris Agreement on climate change. https://eur-lex.europa.eu/legal-content/EN/TXT/?uri=CELEX:22016A1019(01)

European Commission. (2020). Missions in Horizon Europe. https://ec.europa.eu/info/horizon-europe_en\#missions-in-horizon-europe

Fernandez, E., Junquera, B., \& Ordiz, M. (2003). Organizational culture and human resources in the environmental issue: a review of the literature. International Journal of Human Resource Management, 14(4), 634-656. https://doi.org/10.1080/0958519032000057628

Filipov, J. V., \& Avdejeva, T. T. (2000). Osnovy razvitiya mestnogo khozyaystva (p. 246). Delo.

Foley, A., \& Olabi, A. G. (2017). Renewable energy technology developments, trends and policy implications that can underpin the drive for global climate change. Renewable and Sustainable Energy Reviews, 68(2), 1112-1114. https://doi.org/10.1016/j.rser.2016.12.065

Hoff, K., \& Stiglitz, J. E. (2000). Modern economic theory and development (p. 459). Oxford University Press.

Kargytė, V., \& Matijošytè, I. (2020). Bioekonomikos pletros perspektyvos Europoje ir Lietuvoje. COVID-19 pandemijos sukelto ekonominio nuosmukio ir žemu iškastinio kuro kainu veiksnių vertinimas. Lietuvos biotechnologų asociacija. https://www.vdu. 1t/wp-content/uploads/2020/06/Bioekonomikos_perspektyvos_LBTA_2020_05_29_galut-1.pdf

Kushwaha, G. S., \& Sharma, N. K. (2016). Green initiatives: a step towards sustainable development and firm's performance in the automobile industry. Journal of Cleaner Production, 121, 116-129. https://doi.org/10.1016/j.jclepro.2015.07.072

Lietuvos Respublikos Seimas. (1992). Lietuvos Respublikos aplinkos apsaugos įstatymas. https://e-seimas.lrs.lt/portal/legalAct/lt/ TAD/TAIS.2493/asr

Lietuvos Respublikos Seimas. (1999). Lietuvos Respublikos mokesčio už aplinkos teršima istatymas. https://e-seimas.lrs.lt/portal/ legalAct/lt/TAD/TAIS.80721

Lietuvos Respublikos Seimas. (2012). Lietuvos Respublikos Lietuva 2030 pažangos strategija. https://e-seimas.lrs.1t/portal/lega1Act/lt/TAD/TAIS.425517?positionInSearchResults=0\&searchModelUUID=86e319e1-8f5b-4fa2-afbb-0a132e2d85c7

Ministry of Environment of the Republic Lithuania. (n.d.). Darnus vystymas ir Lietuva. https://am.lrv.lt/lt/veiklos-sritys-1/es-ir-tarptautinis-bendradarbiavimas/darnus-vystymasis/darnus-vystymasis-ir-lietuva

McCann-Erickson. (2007). Can sustainability sell? UNEP. http://www.rumbosostenible.com/wp-content/uploads/MCCann_ Can-sustainability-sell.pdf?257bb3

Ministry of Environment of the Republic Lithuania. (2020). Lietuvos Respublikos Nacionalinis energetikos ir klimato srities veiksmu planas 2021-2030 m. https://am.lrv.lt/uploads/am/documents/files/KLIMATO\%20KAITA/Integruotas\%20planas/ Final\%20NECP.pdf 
Ministry of Environment of the Republic Lithuania. (2019). Pasidalyta sèkminga Lietuvos užstato sistemos patirtimi. https://am.lrv. 1t/lt/naujienos/pasidalyta-sekminga-lietuvos-uzstato-sistemos-patirtimi

Ning, Y., Liu, Z., Ning, Z., \& Zhang, H. (2018). Measuring eco-efficiency of state-owned forestry enterprises in Northeast China. Forests 2018, 9(8), 455, 1-13. https://doi.org/10.3390/f9080455

Organisation for Economic Co-operation and Development. (2019). OECD work on Green Growth 2019-20. https://issuu.com/ oecd.publishing/docs/gg_brochure_2019_web

Oželienè, D. (2019). Imonés darnios plètros veiksniu modeliavimas [Doctoral dissertation, Vilnius Gediminas Technical University, Lithuania]. https://doi.org/10.20334/2019-052-M

Sen, A. (1999). Development as freedom. Oxford University Press.

Soewarno, N., Tjahjadi, B., \& Fithrianti, F. (2019). Green innovation strategy and green innovation: The roles of green organizational identity and environmental organizational legitimacy. Management Decision, 57(11), 3061-3078. https://doi.org/10.1108/MD-05-2018-0563

Stern, N. (2002). Strategy for development (p. 172). The World Bank Publications. https://doi.org/10.1596/0-8213-4980-5

Šimelevič, K., \& Bagdzevičienè, R. (2002). Regionalizacijos procesas - vienas iš svarbiausiu veiksniu užtikrinančių regionu ekonomine plètrą. Lietuvos regioninių tyrimų institutas. http://www.lrti.lt/veikla/publikacijos.html

Tseng, M. L., Wang, R., Chiu, A. S. F., Geng, Y., \& Lin, Y. H. (2013). Improving performance of green innovation practices in uncertainty. Journal of Cleaner Production, 40, 71-82. https://doi.org/10.1016/j.jclepro.2011.10.009

United Nations. (2015). 2030 Agenda for Sustainable Develoment. https://www.un.org/ga/search/view_doc.asp?symbol=A/ $\mathrm{RES} / 70 / 1 \&$ Lang=E

United Nations Climate Change. (2020). Adoption of the Paris Agreement. https://unfccc.int/resource/docs/2015/cop21/eng/109.pdf

Zakarevičius, P. (2002). Vadyba: geneze, dabartis, tendencijos. VDU leidykla. 